\title{
Erratum: Biotech financing retrenches in Q2
}

Stacy Lawrence

Nat. Biotechnol. 24, 883 (2006); published online 9 August 2006; corrected after print 8 November 2006.

In the version of this article initially published, the bars in the chart "Global biotech industry financing" on page 883, and their corresponding numbers have been transposed top-to-bottom and do not match. The amount raised is also \$ billions and not \$ millions, as stated. The corrected figure is shown here.

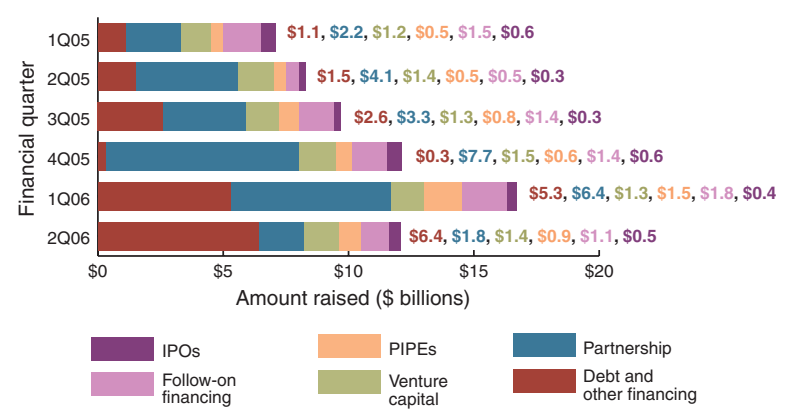

\section{Erratum: Polyclonal antibodies step out of the shadows}

Emily Waltz

Nat. Biotechnol. 24, 1181 (2006); published online 5 October 2006; corrected after print 8 November 2006.

In the version of this article initially published, Symphogen's Symplex technology was said on page 1181, paragraph 5, to involve phage display. That is incorrect; it involves direct PCR cloning, expression and screening of antibodies from B lymphocytes. In paragraph 6, line 3, John Haurum was described as Symphogen's Chief Financial Officer; he is the Chief Scientific Officer. In paragraph 6, line 9, "Symphogen has partnered with AstraZeneca," is incorrect; it has partnered with Stockholm-based Biovitrum.

\section{Corrigendum: Can science resolve the ethical impasse in stem cell} research?

Evan Y Snyder, Lawrence M Hinman \& Michael W Kalichman

Nat. Biotechnol. 24, 397-400 (2006); published online 29 March 2006; corrected after print 8 November 2006.

In the version of this article initially published, on page 399, column 2, paragraph 4, the authors wrongly credited the idea for using cells from nonviable human embryos as an alternative source of human embryonic stem cells to Landry and Zucker (refs. 7,26). The reference should have been to Alikani, M. \& Willadsen, S.M., Reproductive BioMedicine Online 5, 56-58, 2002. 